\title{
DEWASAREJO (Desa Wisata Salak Jatirejo) : Peningkatan Potensi Tanaman Salak Sebagai Peluang Usaha Baru di Jatirejo Diwek Jombang
}

\author{
Umi Kulsum Nur Qomariah ${ }^{1}$, Moh. Faridl Darmawan ${ }^{2}$, \\ Mochammad Syafiuddin Shobirin ${ }^{3}$, dan Nanda Risky Ardiana ${ }^{4}$ \\ Universitas KH. A. Wahab Hasbullah ${ }^{1,2,3}$, STKIP Jombang ${ }^{4}$ \\ umiqomariah@gmail.com ${ }^{1}$, emailecakpar@gmail.com ${ }^{2}$, syafiuddinshobirin@gmail.com \\ denrisky17@gmail.com ${ }^{4}$
}

\begin{abstract}
Jatirejo Village on Diwek Subdistrict Jombang Regency has an abundance of zalacca plants (Salacca zalacca) which are spread in almost every house, especially in Jatirejo hamlet. Zalacca productivity is now decreasing because it is allowed to grow naturally in nature without proper care. Zalacca productive land began to decrease, changing its function to become a settlement along with population growth. Zalacca plants that have been cultivated by the people of Jatirejo actually can be optimized for more economic value. The abundance of salak plants in Jatirejo has the potential to be used as the object of Salak Agro Tourism or on Jatirejo Village.The purpose of community service to initiate the formation of the Salak Jatirejo Tourism Village (Dewasarejo). The method of implementation there are, observing, identification, socializing and coordinating with partners, make over of salak garden, salak festival, promotion and operation of Ngisor Wit Salak Snack Market. The results of this community partnership service show that the presence of Dewasarejo has increased the potential of zalacca plants as a new business opportunity and increased the income of the people of Jatirejo especially at the end of every week through Ngisor Wit Salak Snack Market activities in Dewasarejo.
\end{abstract}

Keywords: village tourism, agro tourism, zalacca garden, Jombang, Salacca zalacca.

\begin{abstract}
Abstrak
Desa Jatirejo Diwek Jombang memiliki kelimpahan tanaman salak (Salacca zalacca) yang tersebar di hampir setiap rumah penduduk terutama di dusun Jatirejo. Produktivitas tanaman salak kini semakin menurun karena dibiarkan tumbuh begitu saja di alam tanpa perawatan yang baik. Lahan produktif salak mulai berkurang, beralih fungsi menjadi pemukiman seiring dengan pertumbuhan penduduk. Tanaman salak yang sudah dibudidayakan masyarakat Jatirejo, sesungguhnya dapat dioptimalkan manfaatnya agar bernilai ekonomi lebih. Kelimpahan tanaman salak di Jatirejo berpotensi untuk dijadikan sebagai objek Agrowisata Salak atau Desa Wisata Salak di Desa Jatirejo. Pengabdian masyarakat ini bertujuan untuk menginisiasi pembentukan Desa Wisata salak Jatirejo (Dewasarejo). Metode pelaksanaan meliputi, observasi, identifikasi, pembuatan kebun salak, festival salak, promosi dan pengoperasian Pasar Jajan Ngisor Wit Salak. Hasil pengabdian kemitraan masyarakat ini menunjukkan bahwa keberadaan Dewasarejo telah meningkatkan potensi tanaman salak sebagai peluang usaha baru dan meningkatkan pendapatan masyarakat Jatirejo terutama di setiap akhir pekan melalui aktivitas Pasar Jajan Ngisor Wit Salak di dalam Dewasarejo.
\end{abstract}

Kata Kunci: desa wisata, agrowisata, kebun salak, Jombang, Salacca zalacca. 


\section{Pendahuluan}

Desa memiliki karakter unik dan variatif yang tidak sama wilayah satu dengan lainnya baik aspek sosial, ekonomi, budaya dan lingkungannya. Karakter yang unik dan spesifik itu menjadikan desa dapat dikembangkan sesuai dengan potensinya. Pedesaan atau kampung memiliki peluang yang besar jika dikembangkan menjadi obyek wisata, karena menjanjikan brand image yang beda (Samidjo dkk, 2016).

Desa Jatirejo memiliki kelimpahan tanaman salak yang tersebar hampir di setiap pekarangan rumah masyarakat, terutama di dusun Jatirejo. Tanaman salak Jatirejo merupakan warisan turun temurun dari generasi terdahulu, sejak zaman perang kemerdekaan Indonesia. Tanaman salak Jatirejo telah berumur cukup tua, dan dibiarkan tumbuh begitu saja dengan tidak mendapatkan perawatan yang baik oleh masyarakat setempat sehingga kurang produktif dalam berbuah. Lahan produktif salak sedikit demi sedikit mulai berkurang, beralih fungsi menjadi pemukiman seiring dengan pertumbuhan penduduk yang semakin bertambah dari waktu ke waktu. Beberapa pohon salak yang berada di rumah warga juga ditebang karena memilih budidaya tanaman palawija, singkong dan umbi-umbian lainnya karena dianggap memiliki nilai ekonomi yang lebih menguntungkan dibanding buah salak. Seiring dengan pertambahan jumlah penduduk dari tahun ke tahun, penebangan pohon salak yang masih produktif menjadi satu hal yang sangat disayangkan.

Tanaman salak yang sudah dibudidayakan oleh masyarakat Jatirejo, sesungguhnya dapat dioptimalkan manfaatnya agar bernilai ekonomi lebih. Kelimpahan tanaman salak di Jatirejo berpotensi untuk dijadikan sebagai objek Agrowisata Salak atau Desa Wisata Salak di Desa Jatirejo. Topografi desa Jatirejo yang masih alami dan memiliki kekhasan sosial budaya, sangat mendukung untuk dijadikan sebagai Desa Wisata. Kawasan pedesaan dewasa ini banyak dipilih sebagai tempat untuk berwisata (Hadiwijoyo, 2012). Desa wisata biasanya memiliki kecenderungan kawasan pedesaan yang memiliki kekhasan dan daya tarik sebagai tujuan wisata (Wiendu, 1993). Pembangunan desa Wisata ini merupakan realisasi dari pelaksanaan Undang-Undang Otonomi Daerah (UU No. 22 Tahun 1999). Realisasi desa wisata berbasis tanaman salak diharapkan dapat menunjang perekonomian masyarakat Jatirejo dan sekitarnya serta konservasi tanaman salak endemik secara berkesinambungan dimana buah salak Jatirejo memiliki kekhasan rasa dibanding salak di tempat lain. Lokasi Desa Jatirejo terletak di dekat Komplek Wisata Religi Gus Dur. Posisi geografis Jatirejo mudah diakses dan berjarak sekitar $3 \mathrm{~km}$ dari komplek wisata religi Gus Dur. Kedekatan lokasi ini akan memudahkan promosi dalam menarik wisatawan luar daerah. Bentang alam Jatirejo yang masih asri dengan suasana pedesaan alami dan terdapat sungai dan persawahan di dalamnya, bisa menjadi daya tarik apabila dijadikan sebagai Agrowisata. Bila desa wisata Jatirejo ini terealisasi, kedepannya wisatawan juga akan disuguhkan dengan melihat langsung proses pembuatan produk olahan salak seperti sari buah salak dan dodol buah salak hasil inovasi Kelompok Wanita Tani (KWT) dan ibu-ibu PKK Jatirejo.

Inisiasi yang mengarah kepada pembentukan desa wisata salak di Jatirejo dipandang perlu untuk disegerakan. Pemberdayaan masyarakat terutama para pemuda, ibu-ibu PKK dan kelompok wanita tani perlu dilakukan dalam rangka mengurangi angka penganggruran usia produktif melalui inisiasi desa wisata salak di Jatirejo. Masyarakat Jatirejo perlu diedukasi terkait potensi yang terdapat di wilayahnya. Oleh karena itu, maka Program Kemitraan antara Universitas KH. A. Wahab Hasbullah dengan Desa Jatirejo perlu dilakukan demi pemberdayaan pemuda dan ibu-ibu PKK untuk mewujudkan terbentuknya desa wisata salak Jatirejo. Pengusul akan menginisiasi terbentuknya 
desa wisata salak (agrowisata) di Jatirejo, sedangkan mitra dalam hal ini berperan sebagai pengelola dan pelaksana program.

Pengabdian kemitraan masyarakat ini bertujuan untuk menginisiasi pembentukan desa wisata salak dalam rangka peningkatan potensi tanaman salak sebagai upaya membuka peluang usaha baru bagi masyarakat Jatirejo Diwek Jombang.

Luaran kegiatan pengabdian ini berupa 1) terbentuknya sebuah desa wisata yang berbasis tanaman salak dengan tanpa mengesampingkan kearifan lokal dari masyarakat Jatirejo, 2) kegiatan pasar jajan tradisional di dalam Desa Wisata Salak Jatirejo dan 3) peningkatan pendapatan masyarakat Jatirejo.

\section{Pelaksanaan Dan Metode}

Program pengabdian kemitraan masyarakat ini dilaksanakan pada bulan Juni s.d September di desa Jatirejo kecamatan Diwek kabupaten Jombang. Metode yang digunakan meliputi diskusi dan praktik dengan pendekatan permasalahan serta solusi berbasis masyarakat (Participatory Rural Appraisal/PRA). Penerapan metode PRA bertujuan untuk mengungkap secara jelas keinginan masyarakat, memobilisasi sumberdaya lokal guna peningkatan produktivitas, pendapatan masyarakat, stabilisasi dan pelestarian sumberdaya lokal (Daniel dkk, 2008). Upaya pengungkapan potensi dan keinginan masyarakat dilakukan melalui forum diskusi baik individual maupun kelompok (Samidjo, 2016).

Metode pelaksanaan pengabdian yang diterapkan meliputi tiga tahapan, yaitu persiapan, pelaksanaan dan evaluasi.

\section{Persiapan}

Pada tahap persiapan dilakukan perijinan, sosialisasi, koordinasi dan pendekatan kepada masyarakat Jatirejo agar menyadari potensi tanaman salak yang dimiliki, kemudian diajak bersama-sama membangun sebuah desa wisata dan observasi langsung ke kebun salak untuk menentukan titik lokasi yang stategis bersama dengan warga Jatirejo dan Dinas Pertanian Jombang. Pada tahap ini juga dilakukan identifikasi potensi ekonomi, sosial, budaya dan potensi alam lokal yang dapat dieksplorasi.

\section{Pelaksanaan}

Pada tahap pelaksanaan dilakukan permbersihan kebun salak. Kebun salak yang masih berupa "barongan" perlu dibersihkan. Kerja bakti dilakukan di sepanjang jalan menuju gang masuk kebun salak dan penutupan lubang parit saluran air. selanjutnya dilakukan pembuatan kebun salak dengan cara pengecatan paving jalan masuk, pembuatan panggung, gapura selamat datang, gapuro masuk kebun, meja bedhak untuk penjual di kebun salak, pemasangan fotobooth dan pengaturan lansekap di dalam kebun salak oleh tim kreatif. Pembukaan Dewasarejo diawali dengan diadakannya festival salak yang dilakukan dengan mengarak gunungan salak sebagai salah satu cara promosi. Promosi juga dilakukan dengan melalui pamflet promosi yang dipublikasikan secara online melalui sosial media instagram dan Facebook. Di dalam kebun salak Dewasarejo secara rutin setiap akhir pekan dibuka Pasar Jajan Ngisor Wit Salak yang mengadopsi penjual makanan tradisonal olahan rumahan masyarakat sekitar.

\section{Evaluasi}

Evaluasi dilakukan dengan melalui penyebaran angket untuk mengidentifikasi sejauh mana respon penjual dan pengunjung terhadap manfaat atas keberadaan Dewasarejo, kemudian angket yang telah diisi dianalisis secara deskriptif kualitatif.

\section{Hasil dan Pembahasan}

\section{Sosialisasi dan Koordinasi}

Sosialisasi dan koordinasi dilakukan untuk menggali keinginan masyarakat dan penjelasan, maksud dan tujuan program pengabdian. Tahap ini dilakukan secara 
berjenjang yang dimuai dengan pendekatan kepada kepala desa beserta perangkat desa Jatirejo kemudian dilakukan diskusi antara masyarakat dengan pelaksana pengabdian masyarakat. Hasil sosialisasi dapat dijabarkan sebagai berikut:

1. Masyarakat bersepakat bahwa di Jatirejo akan mulai dibangun sebuah desa wisata, bukan sebuah wisata desa. Desa wisata akan dibangun dengan berbasis tanaman salak sebagai potensi alam yang terdapat di Jatirejo.

2. Titik lokasi desa wisata dipusatkan di satu titik kebun salak yang memiliki akses jalan yang mudah dijangkau calon pengunjung.

3. Pembersihan akses jalan menuju titik lokasi desa wisata melalui kerja bakti bersama warga.

4. Pembersihan dan penataan kebun salak terpilih untuk dikondisikan dari yang awalnya "sebuah barongan" untuk dibuka dan diatur supaya layak dan aman untuk dikunjungi menjadi sebuah desa wisata.

5. Dibentuk calon pengelola desa wisata salak Jatirejo yang terdiri dari para pemuda dan penggerak desa.

6. Di dalam desa wisata salak Jatirejo akan dibuat kegiatan Pasar Jajan Ngisor Salak yang dibuka setiap akhir pekan. Penjual bersal dari masyarakat Jatirejo.

7. Kelompok Wanita Tani (KWT) Jatirejo mengkoordinasi dan mengkondisikan para warga yang akan berjualan di dalam area Dewasarejo.

8. Area parkir pengunjung dikelola oleh RT/RW setempat.

Selanjutnya masyarakat diajak memulai persiapan pembangunan area desa wisata pada lokasi yang telah disepakati bersama yang dimulai dengan kerja bakti, pembersihan kebun, pemasangan gapuro depan gang, gapuro depan kebun, pengecatan paving dan serangkaian persiapan untuk festival salak sebagai momen awal pembukaan Dewasarejo.

\section{Identifikasi Potensi Alam dan Masyarakat Jatirejo}

Hasil identifikasi potensi alam dan masyarakat Jatirejo yang layak dikemas dalam konsep desa wisata salak Jatirejo adalah sebagai berikut:

1. Hamparan kebun salak, terdapat di hampir setiap rumah di desa Jatirejo terutama di dusun Jatirejo. Tanaman salak tidak hanya berada di kebun saja, bahkan di telajakan dan di pekarangan rumah tinggal masyarakat. Luas kepemilikan salak bervariasi antara $100 \mathrm{~m}$ sampai dengan 1 ha. Dusun Jatirejo dengan segala potensinya dipilih untuk dijadikan sebagai leading sector pariwisata di desa Jatirejo.

2. Tanaman salak Jatirejo memiliki kekhasan rasa buah salak yang unik, yaitu salak rasa jeruk, rasa duren, rasa mangga dan rasa duren. Buah salak yang dihasilkan tidak terlalu besar, tetapi rasanya cukup manis.

3. Tanaman salak yang dimiliki oleh masyarakat desa Jatirejo merupakan warisan dari generasi sebelumnya, bahkan sudah ada sejak zaman perang kemerdekaan Indonesia melawan penjajahan Belanda dan dulunya dijadikan sebagai tempat persembunyian para pejuang.

4. KWT Jatirejo telah menghasilkan produk olahan dari buah salak berupa minuman sari salak dan dodol salak. Potensi produk olahan salak asli buatan desa Jatirejo bisa dijadikan daya tarik dalam desa wisata.

5. Desa Jatirejo secara geografis terletak tidak jauh (kurang lebih $2 \mathrm{~km}$ ) dari komplek wisata religi makam Gus Dur dan juga Museum Nusantara. Kedekatan suatu area wisata baru dengan wisata yang sudah ada, ke depannya akan memudahkan akses para wisatawan menuju desa wisata salak Jatirejo.

6. Topografi alam yang masih asri dengan desa yang dikelilingi oleh persawahan dan sungai dapat memberikan nuansa ketenangan dan 
kenyamanan para pengunjung dari keramaian hiruk pikuk kota.

\section{Pembangunan Desa Wisata}

Pembangunan Desa Wisata dilakukan di lokasi terpilih. Pada spot ini, dibangun sebuah gapuro Selamat Datang yang bisa dilihat dari depan gang yang menghadap ke jalan desa. Jalanan paving dalam gang masuk digambar dan dicat sedemikian rupa agak lebih menarik tampilannya. Di bagian depan kebun diberi sebuah gapuro kecil sebagai pintu masuk kebun salak seperti terlihat pada gambar 1 .

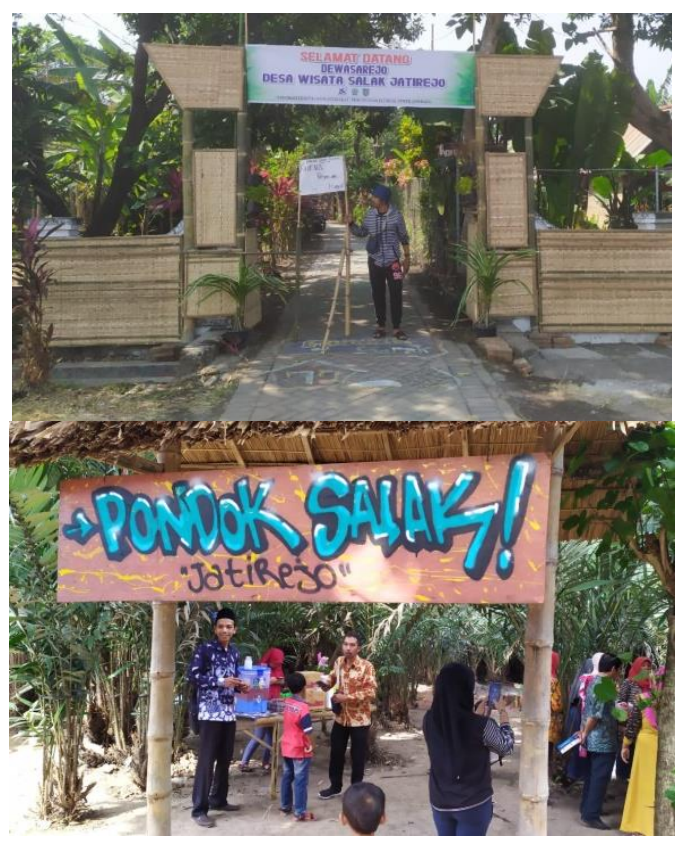

Gambar 1. Gapuro DEWASAREJO, atas: gapuro depan gang masuk, bawah: gapuro depan kebun

Pada hakikatnya sebuah gapura atau gerbang merupakan pintu. Keberadaan gapura/gerbang telah memberi karakter pada citra kawasan disana melalui penerapannya pada akses utama bangunan dalam berbagai fungsi bangunan publik dan bangunan privat (Purnama, 2013). Pemberian Gapura memudahkan akses pengunjung menuju Dewasarejo. Keberadaan gapuro menjadi satu ciri khusus yang membedakan antara gang satu dengan gang lainnya yang bukan merupakan lokasi Desa Wisata. Pengadaan gapuro juga sebagai upaya untuk meningkatkan nilai estetika
Desa Wisata Salak Jatirejo. Pengadaan Gapuro baru dilakukan pada minggu kedua setelah Dewasarejo beroperasi. Evaluasi pada minggu pertama menunjukkan para pengunjung cukup kesulitan menemukan lokasi Dewasarejo karena kurangnya penunjuk arah. Pada minggu kedua setelah adanya gapuro, pengunjung relatif lebih mudah menjangkau lokasi Dewasarejo karena sudah ada gapuro masuk di depan gang (Gambar 1). Hal ini menunjukkan bahwa gapuro mempunyai peran yang vital dalam sebuah desa wisata untuk menarik kedatangan para pengunjung karena tanpa pengunjung maka sebuah desa wisata tidak akan ada artinya.

Di dalam kebun salak yang telah dibersihkan, diisi dengan bedak meja untuk para penjual jajan tradisional, panggung hiburan dan spot swafoto seperti gambar 2 .

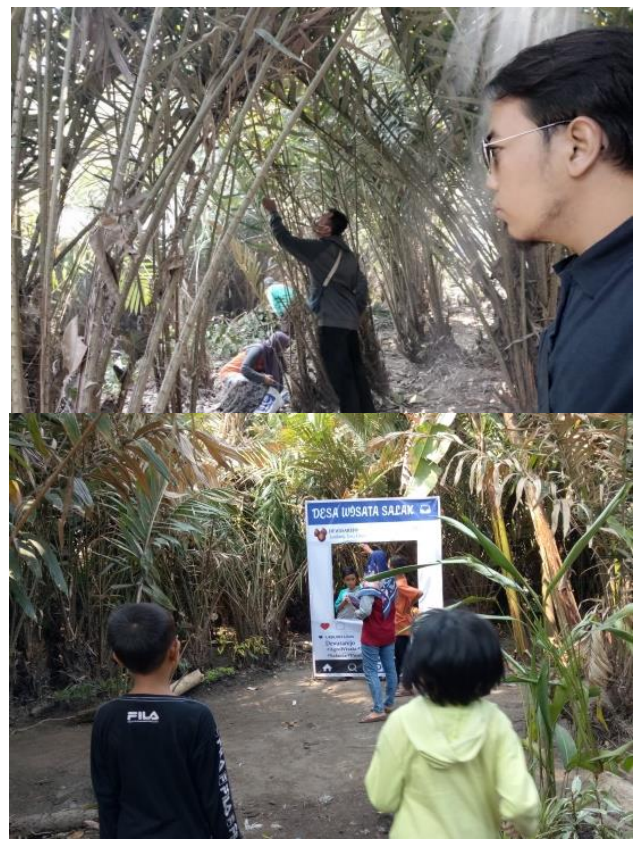

Gambar 2. Kondisi kebun salak, atas: sebelum dibersihkan, bawah: setelah dibersihkan.

Morfologi tanaman salak berakar serabut dan menyerupai pohon palem yang seolah-olah tidak berbatang, rendah dan tegak dengan tinggi tanaman salak antara 1,5- 7 meter, tergantung dari jenisnya. Batangnya hampir tidak kelihatan karena tertutup oleh pelepah daun yang tersusun rapat, pelepah dan tangkai daunnya berduri 
panjang (Steenis, 2013). Pada kegiatan pembersihan kebun salak, dilakukan penjarangan dengan memotong pelepah daun yang berduri dan mengganggu yang posisinya terlalu merunduk ke bawah (Gambar 2 atas). Pembersihan kebun salak menunjukkan hasil yang cukup signifikan. Hasil pengakuan salah seorang pemilik kebun salak bernama Yanti menyatakan bahwa, dahulu warga cukup enggan memasuki kebun salak, namun setelah dibersihkan dan dibuka menjadi sebuah desa wisata, warga mulai berdatangan untuk berkunjung. Pemasangan spot swafoto diantara tanaman salak, menambah kenyamanan para pengunjung untuk berlama-lama dalam kebun salak.

\section{Festival Salak}

Penyelenggaraan festival salak dilakukan dengan beberapa rangkaian acara, diantaranya membuat gunungan salak yang diarak oleh warga. Salak disusun sedemikian rupa dalam bentuk sebuah gunungan dan dikombinasikan dengan segala uborampenya (Gambar 3). Dalam festival salak yang diadakan, turut hadir Bupati selaku pemda Jombang beserta jajarannya, Dinas Pertanian dan perangkat desa Jatirejo berserta jajarannya. Festival salak menjadi penanda dibukanya Dewasarejo sekaligus promosi untuk memperkenalkan Dewasarejo kepada masyarakat Jombang dan sekitarnya. Bersamaan dengan festival salak, juga mulai dibuka Pasar Jajan Ngisor Wit Salak yang berada di dalam lokasi Dewasarejo.

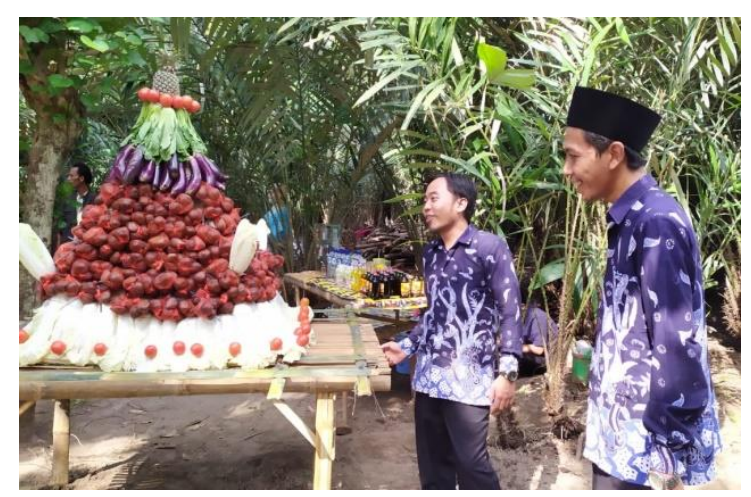

Gambar 3. Gunungan salak dalam acara Festival Salak untuk pembukaan DEWASAREJO
Festival salak ini telah berhasil menarik kedatangan pengunjung ke dalam Dewasarejo. Kebun Salak yang dulunya sepi kini menjadi ramai pengunjung.

Tanaman salak di kebun, produktivitasnya memang menurun seiring dengan berjalannya waktu yang sudah puluhan tahun, tetapi pemilik kebun tetap dapat memperoleh manfaat dari tanaman salak yang di jadikan Dewasarejo. Festival salak dapat berjalan dengan baik berkat adanya kerjasama antara tim peneliti, mitra desa Jatirejo, Dinas Pertanian dan Pemda Jombang.

\section{Pasar Jajan Ngisor Wit Salak Sebagai Peluang Wirausaha Baru}

Pasar Jajan Ngisor Wit Salak mulai beroperasi sejak diadakannya Festival Salak yang berada di dalam kebun Dewasarejo. Di dalam kebun disediakan bedhak meja sebagai tempat berjualan. Para penjual berasal dari warga Jatirejo sendiri. Aneka jajanan tradisional buatan rumahan ditampilkan sedemikian rupa. Setiap penjual ditarik biaya operasional oleh pengelola Dewasarejo, yang digunakan untuk menjaga kebersihan dan menghadirkan hiburan di dalamnya. Dalam praktiknya, Pasar Jajan Ngisor Wit Salak kemudian beroperasi setiap akhir pekan. Hasil analisis data dari sebaran angket kepada 23 responden penjual menunjukkan bahwa keberadaan pasar Jajan ngisor salak, terbukti mampu meningkatkan penghasilan para penjual di dalamnya (Gambar 4).

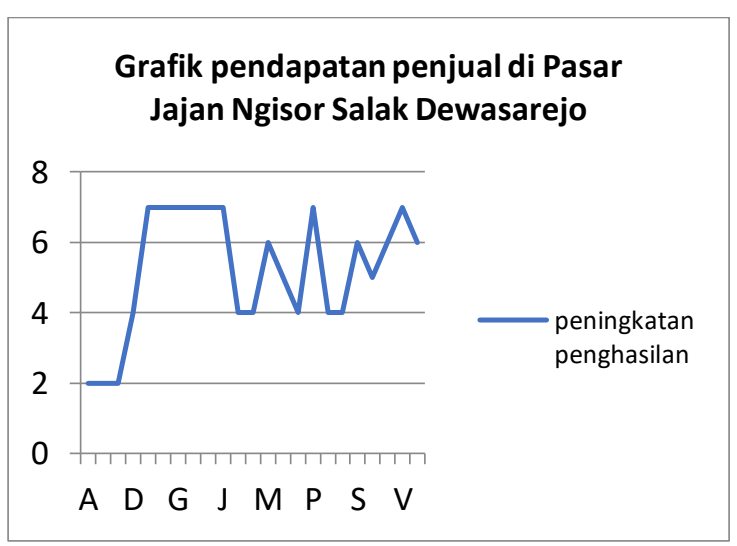

Gambar 4. Grafik peningkatan penghasilan warga Jatirejo yang berjualan di DEWASAREJO. 
Sebanyak 35\% responden (8 orang) menunjukkan peningkatan penghasilan yang cukup signifikan (grafik di angka 7) di setiap akhir pekan. Hal ini disebabkan karena responden tersebut pada hari weekday tidak berjualan dan hanya berjualan ketika Pasar Jajan Ngisor Wit Salak beroperasi. Sebelum pasar ini beroperasi, mereka tidak berjualan di setiap akhir pekan. Secara nyata, keberadaan Pasar Jajan Ngisor Salak menjadi suatu peluang wirausahan baru yaitu ajang untuk berjualan warga Jatirejo. Hal ini telah sejalan dengan yang dikemukakan oleh Murniati dkk (2018) bahwa desa wisata bukan hanya menjadi sebuah status saja, akan tetapi dengan lahirnya Desa Wisata maka secara otomatis roda perekonomian rakyat di desa mampu terus bergerak sehingga mendorong kesejahteraan masyarakat.

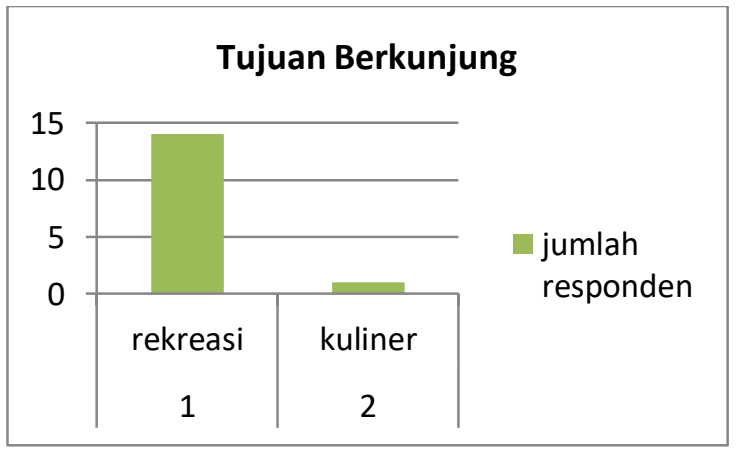

Gambar 5. Diagram tujuan berkunjung wisatawan Dewasarejo

Pada analisis data pengunjung yang juga dilakukan dengan penyebaran angket kepada 15 responden, sebanyak 93\% pengunjung bertujuan untuk rekreasi atau liburan di akhir pekan dan sebanyak 7\% saja yang bertujuan untuk wisata kuliner (Gambar 5). Para pengunjung Dewasarejo umumnya datang bersama keluarga atau sahabat yang dimungkinkan pada weekday mereka jarang bertemu (Gambar 6).

Menurut Nickerson dan Jurowski (2001), perjalanan liburan keluarga meningkat sejalan dengan meningkatnya pendapatan orang tua-pekerja (suami-istri yang bekerja), yang mempunyai waktu terbatas untuk anak-anak mereka. Mereka memanfaatkan liburan sebagai sarana untuk mempererat kembali ikatan keluarga.

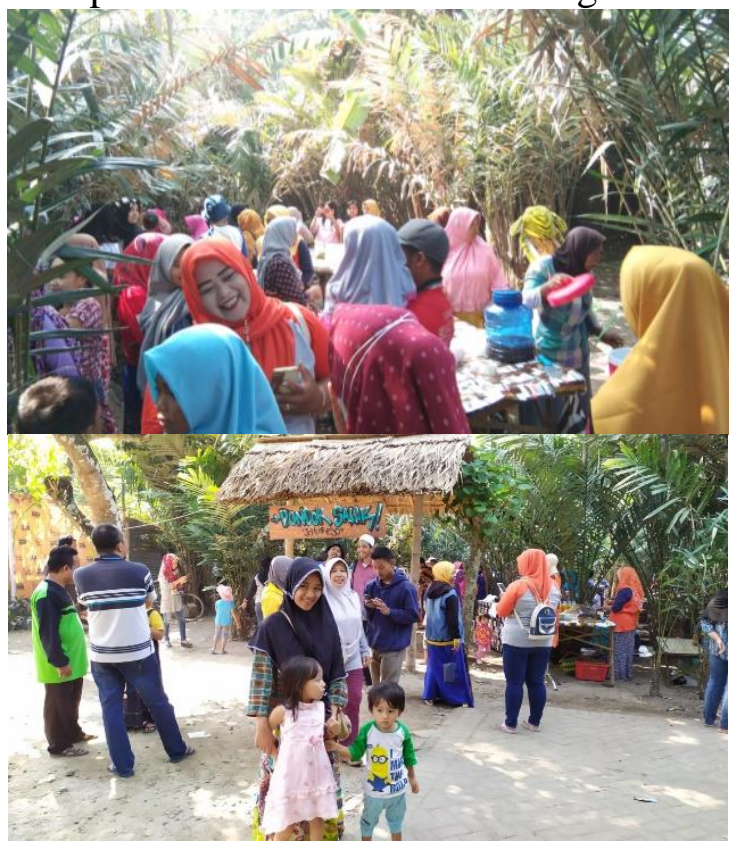

Gambar 6. Pengunjung Pasar jajan ngisor Wit Salak Dewasarejo

Ingkadijaya (2016) menambahkan Fenomena ini menunjukkan bahwa keluarga suami-istri yang bekerja sudah menyadari kekurangan mereka dalam menjalin komunikasi dan relasi dengan anak-anak pada kehidupan sehari-hari. Mereka berusaha memperbaiki hubungan antar anggota keluarga dengan memanfaatkan waktu luang untuk berkumpul bersama dalam bentuk rekreasi atau perjalanan liburan keluarga. Namun, kebutuhan berwisata bukan hanya dimiliki keluarga suami-istri pekerja saja, keluarga yang salah satu atau kedua suami-istri tidak bekerja pun memiliki kebutuhan tersebut. Hal ini disebabkan setiap orang perlu keluar sementara dari rutinitasnya untuk memperoleh keseimbangan dalam hidupnya, sehingga terhindar dari stres dan kejenuhan. Bahkan bagi seorang ibu rumah tangga yang sehari-hari mengurusi persoalan kerumahtanggaan, rutinitasnya lebih membosankan. Kebosanan serupa juga dapat terjadi pada keluarga suami-istri tidak bekerja karena, misalnya, sudah pensiun. Mereka perlu berwisata dengan seluruh 
anggota keluarga untuk mencairkan kebosanannya.

\section{Peningkatan Potensi Tanaman Salak}

Jika menilik kondisi fisiologis tanaman Salak Jatirejo yang sudah berumur puluhan tahun tanpa peremajaan dan perawatan yang baik, adalah sebuah kewajaran apabila produktivitas tanaman salak kini semakan menurun seiring dengan berjalannya waktu. Namun demikian, sekumpulan tanaman salak yang sudah tidak produktif bukan berarti sudah tidak bermanfaat lagi. Kegigihan Tim PKM bersama dengan masyarakat Jatirejo sebagai mitra dalam merintis sebuah Desa Wisata Salak, kini telah membuahkan hasil. Kebun salak telah dijadikan sebuah lahan untuk berjualan yang mampu membuka peluang wirausaha baru, baik bagai pemilik kebun salak maupun warga yang tidak memiliki kebun salak, melalui kegiatan Pasar JajaN Ngisor Wit salak. Masyarakat Jatirejo dapat berpartisipasi untuk turut serta membuka bedak jualan di dalam kebun Dewasarejo seeai dengan ketetuan Pengelola yang dallam hal ini adalah Kelompok Wanita Tani (KWT) dan para pemuda Jatirejo. Dengan demikian, tanaman salak yang sudah tidak produktif dalam berbuah tidak perlu ditebang lagi.

\section{Penutup}

\section{Simpulan}

Program Kemitraan Masyarakat berupa inisiasi pembentukan Desa Wisata Salak Jatirejo (Dewasarejo) telah terlaksana dan diapresiasi dengan baik oleh masyarakat Jatirejo, pemerintah desa dan Dinas Pertanian Jombang. Keberadaan Dewasarejo telah meningkatkan potensi tanaman salak dan membuka peluang wirausaha baru yang dapat meningkatkan pendapatan masyarakat Jatirejo.

Faktor pendukung keberadaan Dewasarejo yaitu kondisi sosial budaya masyarakat yang menyukai gotong royong. Letak geografis DEWASAREJO yang berada di dekat komplek wisata religi Gus
Dur dan Museum Nusantara kedepannya berpeluang untuk dikembangkan dan mendukung promosi. Faktor penghambat saat ini yaitu belum terbentuknya POKDARWIS (Kelompok Sadar Wisata) sebagai penggerak aktif dan terstruktur dalam hubugannya dengan Dinas Pariwisata Jombang.

\section{Saran}

Keberlangsungan pembangunan dan promosi Dewasarejo diperlukan pendampingan intensif agar tetap bisa dijalankan oleh masyarakat Jatirejo setelah program Kemitraan ini selesai. Disarankan bagi para pengelola Dewasarejo yaitu masarakat Jatirejo untuk membangun kerjasama dengan pengelola wisata religi Gus Dur dalam rangka peningkatan promosi Dewasarejo.

\section{Ucapan Terima Kasih}

Ucapan terimakasih disampaikan kepada LPPM Universitas KH. A. Wahab Hasbulllah yang telah mendukung pelaksanaan kegiatan Program Kemitraan Masyarakat dan Kementerian Ristekdikti sebagai sponsor dalam program hibah bersaing pengabdian Masyarakat tahun 2019. Terimakasih juga disampaikan kepada mitra yaitu masyarakat dan Pemerintah Desa Jatirejo khususnya Kelompok Wanita Tani (KWT) Jatirejo.

\section{Daftar Pustaka}

Daniel M, Darmawati dan Nieldalina. 2008. PRA: Pendekatan Efektif Mendukung Penerapan Penyuluhan Partisipatif dalam Upaya Percepatan Pembangunan Pertanian. Bumi Aksara, Jakarta.

Hadiwijoyo, Suryo S. 2012. "Perencanaan Pariwisata Perdesaan Berbasis Masyarakat (Sebuah Pendekatan Konsep)"1 st ed., Graha Ilmu, Yogyakarta.

Ingkadijaya R. 2016. Motif, Aktivitas, Kepuasan Berwisata, dan Kontribusinya pada Kepaduan 
Keluarga. Universitas Gadjah Mada, 2-3.

Murniati K, Zakaria W, Arifin B dan Indah LSM. 2018. Pengembangan Potensi Desa Sungai Langka Sebagai Desa Agrowisata di Kabupaten Pesawaran. Laporan Akhir Pengabdian Masyarakat. Universitas Negeri Lampung, 5.

Nickerson N P, Jurowski C. 2001. The in $^{-}$uence of children on vacation travel patterns. Journal of Vacation Marketing, Vol. 7 No. 1, 19-30.

Purnama, I. 2013. Penerapan Material Bata Pada Gapura/Gerbang Masuk Bangunan Elemen Pembentuk Estetika Perkotaan di Kota Cirebon. Seminar Nasional SCAN\#4. 129135.

Samidjo G S, Wibowo S, Sutrisno. 2016. Pengembangan Desa Wisata Belajar Berbasis Potensi Alam dan Pertanian di Polengan, Srumbung, Magelang. Jurnal Berdikari. Vol.4 No.1 Februari 2016, 44-53.

Samidjo, Gatot S. 2016. Kajian SpasialEkologi Varietas Padi pada Berbagai Ekosistem Sawah Irigasi dalam Rangka Pembangunan Pertanian Berkelanjutan. Disertasi Program Doktor Ilmu Lingkungan, Sekolah Pascasarjana UGM.

Steenis CCGJ. 2013. Flora. Balai Pustaka: Jakarta. 